\title{
Uji Kelayakan Teh Herbal Kulit Batang Tali Kuning (Arcangelisia flava (L.) Merr)
}

\section{Feasibility Analysis of Herbal Tea from the Steam Bark of Yellow Rope (Archangelisia flava (L.) Merr)}

\author{
Alowisya Futwembun ${ }^{1}$,Yuliana Ruth Yabansabra ${ }^{2 *}$, Nurhairi ${ }^{3}$ dan Desinta O. Sitokdana ${ }^{4}$ \\ ${ }^{1234}$ Jurusan Kimia, Fakultas Matematika dan Ilmu Pengetahuan Alam, Universitas Cenderawasih, \\ Jayapura \\ *Koresponden:yyabansabra@ yahoo.com
}

\begin{abstract}
Abstrak
Teh adalah minuman yang mengandung kafein, sebuah infusi yang dibuat dengan cara menyeduh daun, pucuk daun, atau tangkai daun yang dikeringkan dari tanaman Camellia sinensis dengan air panas. Teh Herbal adalah sebutan racikan bunga, daun, biji, akar, atau buah kering untuk membuat minuman yang juga disebut teh herbal. Penelitian ini bertujuan untuk mengetahui kelayakan ekstrak kulit batang tali (akar) kuning (A. flava) sebagai teh herbal. Hasil yang didapatkan dari penelitian ini yaitu : kadar air $0,24 \%$, kadar ekstrak dalam air 42,38 \%, kadar serat kasar 1,04\%, kadar abu larut dalam air dari abu total 3,37 \%, kadar alkalinitas abu larut dalam air (sebagai $\mathrm{KOH}$ ) \%, kadar abu total 1,78 \%, kadar abu tak larut dalam asam 0,01 \% dan juga terdapat senyawa metabolit sekunder seperti: tanin, saponin dan flavanoid yang berguna dan bermanfaat bagi tumbuhan dan manusia. Uji kualitatif tersebut telah menghasilkan delapan parameter yang sesuai dengan SNI 3836:2013 Teh Kering dalam Kemasan.
\end{abstract}

Kata Kunci :Kelayakan,Teh herbal,Kulit Batang Tali Kuning.

\section{Abstract}

Tea is a beverage that contains caffeine, as an infusion made by brewing leaves, dried leaves, or petioles from camellia sinensis plant with hot water. Herbal tea is the name of a mixture of flowers, leaves, seeds, roots, or drierd fruit to make a drink which is also called herbal tea. This study aims to determine the feasibility of bark extract, yellow rope (root) (A. flava) as an herbal tea.The result of this study were obtained: water content $0,24 \%$, levels extract in water $42,38 \%$, fiber content rude 1,04\%, ash content soluble in water from soluble in water from dust total 3,37 \%, levels alkalinity dust soluble in water (as KOH) 2,93\%, ash contect total 1,78\%, ash content insoluble in acid 0,01\%, and also compounds metabolites secondary such as tannins, saponin, and flavonoids which are useful for plants and human. The qualitative test have produced eigth parameters that were in accordance with SNI 3836:2013 dry tea in packaging.

Keywords :Feasibility Analisis Herbal Tea, Yellow String Bark

\section{PENDAHULUAN}

Peningkatan kesehatan merupakan modal untuk memajukan taraf hidup masyarakat. Berbagai cara dilakukan untuk meningkatkan taraf hidup masyarakat, salah satunya adalah pengadaan obat-obatan yang berasal dari alam. Pemanfaatan tumbuhan sebagai obat tradisional bukanlah hal yang baru. Hampir setiap suku di berbagai negara mempunyai budaya dalam memilih tumbuhan sebagai obat tradisional (Rosye, dkk., 2018). Salah satu tumbuhan yang digunakan dalam pengobatan tradisonal adalah tumbuhan tali/akar kuning (Archangelsia flava). Tumbuhan ini merupakan tumbuhan merambat yang tumbuh di daerah tropis dan merupakan tumbuhan asli Indonesia. Pemanfaatan tali kuning sebagai obat 
tradisional oleh masyarakat Papua khususnya etnik atau suku Moy yang berada di kabupaten Jayapura Papua telah digunakan sejak zaman dahulu hingga sekarang. Masyarakat etnik Moy meyakini bahwa ekstrak seduhan kulit batang tali kuning dapat meningkatkankesehatan dan menyembuhakan beberapa penyakit misalnya: capek-capek, demam, malaria, hepatitis dan menurunkan kadar gula didalam darah.Tali kuning juga dimanfaatkan di beberapa daerah untuk meningkatkan kualitas kesehatan misalnya masyarakat di Kalimantan, Sulawesi dan Ambon juga memanfaatkan ekstrak tumbuhan ini untuk kesehatan dan penyembuhan beberapa penyakit demam, cacingan, hepatitis dan lain sebagainya (Rachmawati dan Ulfa, 2018).

Ekstrak kulit batang tali kuning juga diyakini dapat menurunkan kadar kolesterol total, trigliserida, dan LDL tikus hiperlipidenia selain itu juga dilaporkan bahwa ekstrak tali kuning bersifat toksik terhadap hepar dan ginjal (Rachmawati dan Ulfa, 2018). Hasil studi pustaka diketahui bahwa ekstrak batang kuning bersifat sitotoksik terhadap Plasmodium falcifarum penyebab penyakit malaria tropika (Lovinet al.,2012). Selain itu,ekstrak akar kuning memiliki aktifitas sebagai antioksidant dan antidiabetes (Wahyudi, 2016) dan juga memiliki aktifitas antimikroba yang bersifat menstabilkan asam yang berdampak pada produksi gula merah (Hesty\& Nugraho, 2015).

Kandungan senyawa metabolit sekunder didalam tali kuning yang pernah dilaporkan adalah alkaloid dan saponin (Ratnasari, dan Handayani, 2018), selain itu Futwembun et al.,(2018) juga melaporkan bahwa hasil skring fitokimia kulit batang tali kuning mengandung senyawa alkaloid, saponin dan flavonoid. Subeki dalam Weyai, (2015) juga dilaporkan adanya senyawa alkaloid didalam ekstrak batang tali/akar kuning.

Pada penelitian ini kulit batang tali kuning atau akar kuning diolah menjadi teh herbal untuk mempermudah proses konsumsi masyarakat yang awalnya mengunakan kulit kayu dan direbus langsung dengan jumlah serbuk yang terukur secara kuantitatif. Herbal tea atau teh herbal merupakan salah satu produk minuman campuran teh dan tanaman herbal yang memiliki khasiat dalam membantu pengobatan suatu penyakit atau sebagai penyegar. Teh herbal umumnya campuran dari beberapa bahan yang biasa disebut infusi/tisane. Infusi/tisane terbuat dari kombinasi daun kering, biji, kayu, buah, bunga dan tanaman lain yang memiliki manfaat. Syarat mutu teh kering dalam kemasan berdasarkan SNI 3836:2013 adalah kesadahan air seduhan, warna, bau, rasa, flavor dan rangsangan seduhan teh. Penelitian ini 
bertujuan untuk mengetahui kelayakan ekstrak kulit batang tali/akar kuning (A.flava.Merr) sebagai teh herbal.

\section{METODE PENELITIAN}

\section{Bahan dan Alat}

Bahan yang digunakan penelitian ini adalah: serbuk kulit batang tali kuning, kertas saring, etanol, larutan $\mathrm{H}_{2} \mathrm{SO}_{4} 1,25 \%$, larutan $\mathrm{NaOH} 3,25 \%$, larutan $\mathrm{FeCl}_{3} 10 \%, 1 \mathrm{ml} \mathrm{HCl}$, kloroform, $\mathrm{H}_{2} \mathrm{SO}_{4} 2 \mathrm{M}, \mathrm{HCl} 0,1 \mathrm{~N}, 25 \mathrm{ml} \mathrm{HCl} \mathrm{40 \% ,} \mathrm{KI,} \mathrm{I}$, kertas saring bebas abu, dan reagen wagner. Alat yang digunakan di penelitian ini adalah: oven, desikator, neraca analitik, hot plate, penangas air, blender, rak tabung reaksi, botol semprot, statif dan klem, furnace, gelas piala, labu ukur, pipet gondok, labu Erlenmeyer, batang pengaduk, gelas ukur, pendingin tegak, tabung reaksi, cawan porselen, buret, pipet tetes, pembakar spritus, pipet ukur, pipet fitrat, pipet volum, 1 set alat sokhlet, 1 set alat destilasi, dan termometer.

\section{Prosedur kerja}

Kulit batang tali kuning yang telah dibuat menjadi simplisia dilakukan beberapa penetapan parameter sesuai dengan monografi Materi Medika Indonesia (MMI) dan uji kandungan kimia ekstrak sebagai tambahan parameter ekstrak yang mengacu pada prosedur Parameter standar umum ekstrak tumbuhan obat dari Departemen Kesehatan (Anonim, 2000). Uji kualitatif atau skrining fitokimia metabolit sekunder mengikuti prosedur yang dilakukan oleh Marpaung (2017), sedangkan untuk uji parameter spesifik dan nonspesifik mengikuti prosedur SNI.

Penetapan parameter non spesifik meliputi: kadar air, kadar abu total, dan kadar abu tidak larut dalam asam. Sedangkan parameter spesifik meliputi: Identititas, organoleptik, senyawa terlarut didalam pelarut tertentu antara lain air dan etanol.

\section{Uji kualitatif metabolit sekunder}

Mula-mula sampel kulit batang tali atau akar kuning dikuliti lalu dicuci hingga bersih lalu dijemur sambil diangin-anginkan selama kurang lebih lima hari hingga sampel kering merata lalu dihaluskan menggunakan blender dan diayak dengan ayakan. Proses skrining fitokimia diawali dengan mengambil sejumlah 5 gram sampel ditambahkan aquades kemudian didiamkan sebentar. Selanjutnya diuji sebagai berikut: 


\section{Saponin}

Memasukkan 2 gramsampel kedalam tabung reaksi, lalu ditambahkan $5 \mathrm{ml}$ aquadest, dipanaskan dengan lampu spritus. Pada saat mendidih stopwatch dinyalakan dan diatur waktu selama 2 menit. Sampel dikocok sampai terbentuk busa, setelah terbentuk busa didiamkan selama 5 menit. Jika busa bertahan selama 5 menit, sampel positif (+) mengandung saponin.

\section{Tanin}

Menimbang 2 gram sampel lalu dilarutkan denganaquadest panas selanjutnya hasil filtrat di pipet sebanyak $5 \mathrm{ml}$ lalu dimasukkan kedalam tabung reaksilalu ditambahkan 3 tetes $\mathrm{FeCl}_{3} 10 \%$.

\section{Flavonoid}

Menimbang 2 gram sampel dilarutkan dengan akuades panas, dipipet $5 \mathrm{~mL}$ filtrat dimasukkan kedalam tabung reaksi, ditambahkan 0,5 gram serbuk $\mathrm{Mg}$ dan ditambahkan $1 \mathrm{~mL}$ $\mathrm{HCl}$ kemudian kocok kuat-kuat, sampel didiamkan lalu mencatat hasil perubahan warna.

\section{Alkaloid}

Sebanyak 2 gram sampel dilarutkan dengan kloroform dan beberapa tetes $\mathrm{NH}_{4} \mathrm{OH}$ kemudian disaringkedalam tabung reaksi bertutup, ekstrak kloroform dikocok dengan penambahan beberapa tetes $\mathrm{H}_{2} \mathrm{SO}_{4} 2 \mathrm{M}$, setelah terbentuk dua lapisan diambil lapisan bening untuk dianlisis dengan reagen wagner untuk indentifikasi alkaloid.

\section{Uji Parameter spesifik dan non spesifik}

\section{Penetapan Kadar Air (Gravimetri)}

Siapkan semua alat dan bahan, ditimbang dengan teliti sampel yang telah disiapkan sebanyak 2 gram dengan menggunakan cawan penguap yang telah diketahui beratnya. Dipanaskan dalam oven selama 2 jam dengan suhu $105^{\circ} \mathrm{C}$ sampai berat tetap. Selanjutnya menghitung kadar air sampel.

\section{Penetapan kadar ekstrak dalam air (gravimetri)}

Mengambil sebanyak 2 gram sampel lalu tambahkan $100 \mathrm{ml}$ aquadest panas diamkan selama 1 jamlalu disaring kedalam labu ukur $500 \mathrm{ml}$, corong berisi sampel dibilas dengan air panas sampai larutan jernih atau bening, dinginkan kemudian paskan sampai tanda batas.Pipet $50 \mathrm{ml}$ filtrat masukkan kedalam cawan porselen yang telah diketahui beratnya (bobot konstan), keringkan diatas penangas air. Dipanaskan dalam oven selama 2 jam dengan suhu $105^{\circ} \mathrm{C}$ sampai berat tetap. 


\section{Penetapan kadar serat kasar (gravimerti)}

Menimbang 2 gram sampel secara teliti, lalu dimasukkan kedalam Erlenmeyer $250 \mathrm{ml}$, tambahkan ethanol $96 \%$ untuk pembebasan lemak. Larutan tersebutdisaring dengan kertas saring bebas lemak kedalam Erlenmeyer $250 \mathrm{ml}$, keras saring dipisahkan lalu dikeringkan.

Kedalam erlenmeyer ditambahkan $50 \mathrm{ml}$ larutan $\mathrm{H} 2 \mathrm{SO} 4$ 1,25\% refluk selama 30 menit lalu menambahkan $\mathrm{NaOH}$ 3,25\% refluk kembali selama 30 menit. Hasil reflux disaring menggunakan kertas saring bebas abu.Selanjutnya kertas saring dicuci menggunakan larutan $\mathrm{H}_{2} \mathrm{SO}_{4} 1,25 \%$ panas, aquadest panas dan ethanol $96 \%$ masing-masing $25 \mathrm{ml}$, endapan dikeringkan lalu dimasukkan kedalam cawan porselen dipanaskan selama 2 jam dengan suhu $105^{\circ} \mathrm{C}$ sampai berat tetap.

\section{Penetapan kadar abu (gravimetri)}

Menimbang 2 gram sampel kedalam cawan yang telah diketahui beratnya, sampel diabukan dalam furnace pada suhu $425^{\circ} \mathrm{C}$ selama $2 \mathrm{jam}$, abu hasil pengabuan didinginkan lalu ditimbang.

\section{Penetapan kadar alkalinitas abu larut dalam air (sebagai KOH)}

Abu hasil pengabuan dititrasi dengan $\mathrm{HCl} 0,1 \mathrm{~N}$ dan indikator metil orange selanjutnya dihitung jumlah penitran untuk mendapatkan kadar alkalinitas.

\section{Penetapan kadar abu larut dalam air dari abu total (graimetri)}

Contoh yang digunakan adalah abu yang berasal dari penentuan kadar abu total. Kedalam abu contoh ditambahkan $20 \mathrm{ml}$ air suling. Sampel dipanaskan hingga hampir mendidih lalu di saring dengan kertas saring bebas abu. Bilas cawan dan kertas saring beserta isinya dengan air panas hingga jumlah filtrate kira-kira $60 \mathrm{ml}$. Filtrat hasil saringan di gunakan untuk penetapan alkalinitas abu larut dalam air. Kertas saring diuapkan lalu diabukan didalam furnice.Pindahkan kertas saring dan isinya ke cawan semula, uapkan dengan hati-hati di atas penangas air.

\section{Penetapan kadar abu larut dalam asam (gravimetri)}

Contoh uji merupakan abu larut dalam air.Kedalam contoh uji ditambahkan $25 \mathrm{ml}$ $\mathrm{HCl} 40 \%$, tutup cawan selama sepuluh menit di atas penangas air. Dengan menggunakan kertas saring bebas abu sampel disaring lalu dibilas selanjutnyadiabukan kedalam furnice, dinginkan dan saring larutan menggunakan kertas saring tak berabu. Bilas menggunakan air panas hingga air pencuci bebas dari asam. Tempatkan kembali kertas saring dan isi ke dalam 
cawan, uapkan hati-hati di atas penangas air yang mendidih, kemudian panaskan dalam furnace pada suhu $425^{\circ} \mathrm{C}$.

\section{HASIL DAN PEMBAHASAN}

Sampel tali atau akar kuning (A. flava) diperoleh dari hutan kampung Maribu distrik Sentani Barat Kabupaten Jayapura Papua. Sampel kulit batang tali kuning yang telah dibersihkan dijemur untuk mengurangi kadar air sampel selain itu dengan kurangnya kadar air maka potensi tumbuhnya jamur pada sampel akan berkurang. Sampel yang telah bersih dihaluskan untuk memperkecil ukuran sampel dan memperluas permukaan sampel agar senyawa aktif yang terkandung didalam sampel muda berinteraksi dengan pelarut dan muda ditarik oleh pelarut dari dalam serbuk sampel.

Hasil skrining fitokimia metabolit sekunder menunjukan bahwa simplisia kering teh herbal kulit batang tali kuning mengandung sejumlah senyawa metabolit sekunder diantaranya saponin, tanin, flavonoid dan alkaloid. Hal ini teramati dari perubahan warna sampel sebelum dan sesudah penambahan reagen kimia untuk identifikasi senyawa-senyawa metabolit sekunder. Berikut adalah tabel hasil pengamatan skring fitokimia ekstrak teh herbal kulit batang tali akar kuning (A. flava).

Tabel 1. Hasil Skrining Fitokimia

\begin{tabular}{|c|c|c|c|}
\hline $\begin{array}{c}\text { Uji } \\
\text { Fitokimia }\end{array}$ & Pereaksi & Hasil Pengamatan & Kesimpulan \\
\hline \multirow{3}{*}{ Alkaloid } & Mayer & Tidak terbentuk endapan putih & - \\
\hline & Dragendoff & Terbentuk endapan berwarna coklat & + \\
\hline & Wagner & Terbentuk warna coklat kemerahan & + \\
\hline Flavonoid & $\mathrm{Me}-\mathrm{OH}+$ Serbuk $\mathrm{Mg}+\mathrm{HCl}$ pekat & $\begin{array}{l}\text { Warna larutan tetap berwarna } \\
\text { kuning }\end{array}$ & - \\
\hline Terpenoid & Asam Asetan anhidrat $+\mathrm{H}_{2} \mathrm{SO}_{4}$ & Terbentuk lapisan berwarna putih & - \\
\hline Steroid & Asam Asetan anhidrat $+\mathrm{H}_{2} \mathrm{SO}_{4}$ & Larutan tetap berwarna kuning & - \\
\hline Tanin & Aquadest $+\mathrm{FeCl}_{3} 1 \%$ & Larutan tetap berwarna kuning & - \\
\hline Saponin & Aquades panas & Terbentuk buih yang stabil & + \\
\hline
\end{tabular}

Berdasarkan keterangan pada Tabel 1 maka dapat dikatakan bahwa ekstrak kulit batang tali kuning mengandung senayawa alkaloid dan senayawa saponin. Alkaloid adalah senyawa organik berbobot molekul kecil mengandung unsur nitrogen dan memilki efek farmakologi pada manusia dan hewan. Secara alami senyawa alkaloid banyak ditemukan pada tumbuhan (Saihidin, 2015). Senyawa-senyawa alkaloid yang terkandung di dalam tumbuhan dan dimanfaatkan oleh manusia sebagai obat tradisional umumnya memiliki rasa yang pahit dan berperan sebagai pengahambat perkembangbiakan mikroorganisme seperti plasmodium 
dan mikroba lain seperti bakteri dan virus. Selain alkaloid beberapa senyawa saponin juga berperan dalam menimbulkan rasa pahit (Ratnasari dan Handayani, 2018).

Sejalan dengan hasil skring fitokimia ekstrak teh herbal tali kuning juga mengandung alkaloid dan saponin dapat diasumsikan bahwa rasa pahit pada seduhan teh herbal tali kuning berasal dari senyawa alkaloid dan saponin. Selain senyawa saponin ekstrak kulit batang tali kuning juga mengandung senyawa metabolit sekunder dari kelompok alkaloid (Futwembun et at., 2018). Selain itu dilaporkan bahwa bahwa fraksi alkaloid ekstrak kulit batang tali kuning memilki nilai sitotoksik yang sangat baik terhadap $P$. falcifarum hal ini memperkuat asumsi bahwa senyawa-senyawa alkaloid yang terkandung didalam ekstrak teh herbal tali kuning memilki peran sebagai pemberi rasa pahit dan pengehambat perkembangan mikroorganisme penyebab penyakit seperti plasmodium dan beberapa mikroorganisme lain.

Hasil identifikasi alkaloid dengan pereaksi wagner ditandai denganterbentuknya endapan coklat kemerahan, hal ini disebabkan oleh reaksi yang terjadi antara alkaloid dan larutan $\mathrm{I}_{2}$ didalam KI yang membentuk senyawa Kalium-Alkaloid dalam bentuk kelat.

\section{Uji Parameter Spesifik dan Non Spesifik}

Sampel simplisia kulit batang tali kuning yang telah diolah menjadi teh herbal dilakukan pengujian paramater spesifik dan non spesifik untuk mengetahui standar layak tidaknya sampel ini dimasukan dalam kategori teh herbal dan layak dikonsumsi sesuai standar SNI. Hasil uji parameter spesifik dan non spesifik teh herbal tali kuning ditunjukkan pada tabel berikut ini.

Tabel 2. Hasil Uji Parameter Spesifik dan Non Spesifik Sampel Teh Herbal Kulit Batang Tali Kuning

\begin{tabular}{clcc}
\hline No. & \multicolumn{1}{c}{$\begin{array}{c}\text { Hasil Uji Parameter } \\
\text { spesifik dan non spesifik }\end{array}$} & Sampel (\%) & SNI (\%) \\
\hline 1 & Kadar air & 0,24 & Maks. 8 \\
2 & Kadar ekstrak dalam air & 42,34 & 32 \\
3 & Kadar serat kasar & 1,04 & Maks. 16,5 \\
4 & Kadar abu & 2,78 & Maks. 8 \\
5 & Kadar alkalinitas abu larut dalam air & 1,86 & $1-3$ \\
6 & Kadar abu larut dalam air & 1,49 & Min. 45 dari kadar abu total \\
7 & Kadar abu tak larut dalam asam & 0,01 & Maks. 1 \\
\hline
\end{tabular}

Berdasarkan Tabel 2 hasil uji parameter spesifik dan non spesifikkulit batang tali kuning memenuhi standar kelayakan yaitu SNI 3836:2013 teh kering dalam kemasan. Parameter kadar air adalah pengukuran kandungan air yang berada di dalam bahan, yang 
bertujuan untuk memberikan batasan minimal atau rentang besarnya kandungan air dalam bahan. Kadar air dalam ekstrak tidak boleh lebih dari 8\%. Hal ini bertujuan untuk menghindari cepatnya pertumbuhan jamur dalam ekstrak. Kadar air mempunyai peranan yang besar terhadap mutu suatu produk. Kandungan air dalam bahan makanan menentukan kesegaran, masa simpan bahan pangan, karena air dapat mempengaruhi sifat-sifat fisik atau adanya perubahan-perubahan kimia seperti mempengaruhi tekstur, kenampakan, dan cita rasa (Winarno, 1997).

Parameter kadar ekstrak dari teh kulit batang tali kuning menunjukkan terekstrak dengan baik, sehingga mutu dan kualitas teh dari batang tali kuning baik. Parameter lainnya yang sesuai standar yaitu kadar serat kasar. Sehingga mutu teh tersebut sangat baik karena mengandung serat yang dibutuhkan oleh tubuh. Parameter uji lainnya berupa kadar abu, kadar alkalinitas dalam air, dan kadar abu tak larut dalam asam yang sesuai dengan standar kelayakan menunjukkan bahwa kulit batang tali kuning ini dapat dikonsumsi.

\section{KESIMPULAN}

Berdasarkan hasil penelitian dapat disimpulkan bahwa ekstrak teh herbal kulit batang tali atau akar kuning mengandung senyawa metabolit sekunder dari golongan alkaloid dan saponin serta ekstrak ini layak dikonsumsi sebagai teh herbal karena memenuhi Standar Nasional Indonesia (SNI) untuk teh kering dalam kemasan.

\section{REFERENSI}

Anonim, 2000.Parameter Standar Umum Ekstrak Tumbuhan Obat. Ditjen POM RI, Jakarta, Departemen Kesehatan Republik Indonesia Jakarta, 29-36.

Ashariati,2007. Antihiperlipidemia Ekstrak Etanol Batang Kayu Kuning (Arcangelisia flava (L.) Merr.)Terhadap Tikus Putih Galur Wistar Yang Diinduksi Pakan Tinggi Lemak.[Skripsi]. Sekolah Tinggi Ilmu Farmasi "Yayasan Farmasi". Semarang.

Futwembun, A., Holle, E., Yabansabra, Y. R., \& Simaremare, E. S., 2018. The Activity of Anti-Plasmodium of Alkaloid Fraction from Bark Yellow Rape (Archengelsiaflava Merr. (L). Journal of Chemical and Pharmacetical Reasearch. Vol. 10 (11):41-47

Hersty, H. \& Nugroho, A., 2015. Study of Yellow Root (Archangelsia flava.Merr ) as A Natutal Food Additive with Antimicrobal and Acidity-Stabilizing Effects in the Production Process of Palm Sugar. Procedia Environmental Sciences. 23:346-350

Lovin, E. R.,Arwati, H., \& Ramadhani, RB. 2012. In Vitro Intraerythrocytic Antimalarial Activity of Akar Kuning (Arcangelisia flava (L.) Merr.) Stem Aqueous Extract In Plasmodium falciparum. Folia Medica Indonesiana. Vol. 48 (3): 90-95 
Marpaung, M. P., Ahwizar, A., dan Wulandari, W., 2017. Karakterisasi dan Skring fitokimia Ekstrak Kering Akar Kuning (Fibraurea cloroleuca Miers). Prosiding Seminar Nasional Kimia UNY. Sinergi Penelitian dan Pembelajaran untuk Mendukung Pengembangan Literasi Kimia pada Era Global. Hal 145-154

Ratnasari, D., dan Handayani, R.P., 2018. Skrining fitokimia dan Uji Stabilitas Sirup Kayu Kuning (Archangelsia flava) untuk Memlihara Kesehatan. Journal of Holistic and Health Siences. Vol.2 (1):7-13.

Rachmawati, E., dan Ulfa, E.U., 2018. Uji Toksisitas Subkronik Ekstrak Kayu Kuning (Archangelsia flava Merr) terhadap Hepar dan Ginjal.Global Medical and Health Comunication. Vol. 6(1):1-6

Sahidin. I. 2015. Mengenal Senyawa Alami. Pembentukan dan Pengelompokan Secara Kimia. Unhalu Press, Kendari.

Standar Nasional Indonesia. SNI 3836: 2013. Teh kering dalamkemasan. Dewan Standarisasi Nasional.

Rosye, H.R., Suharno, \&Hendra, K.M., 2018. Potensi Tumbuhan Obat Papua. Dialekita. Jogjakarta.

Wahyudi, L. D., Ratnadewi, A. A.I., \& Siswoyo, T. A., 2016. Potential Antioxidant and Antidiabetic Activities of Kayu Kuning (Archangelsia flava). International Conference on Food, Agriculture and Natural Resources, IC-FANRes 2015. Agriculture and Agricultural Science Proseding 9 (2016), pp.396-402.doi: 10.1016/j.aaspro.2016.02.155

Weyai,F. J., 2015. Analisis Antiplasmodium Iientifikasi Struktur Ekstrak Etil Asetat Kulit Batang Tali Kuning (Aracngelsia Flava Merr).[Skripsi]. Jurusan Kimia FMIPA, Universitas Cenderawasih, Jayapura.

Winarno, F. G. 1997. Kimia Pangan dan Gizi. Gramedia Pustaka Utama. Jakarta. 